\title{
Influence of iron and nitrate concentration in water on aquatic Coleoptera community structure: Application to the Avia River (Ourense, NW. Spain)
}

\author{
Marta Fernández-Díaz, Cesar Joao Benetti* and Josefina Garrido
}

Department of Ecology and Animal Biology, Faculty of Biology. University of Vigo, Campus LagoasMarcosende, 36310, Vigo, Spain

* Corresponding author: cjbenetti@uvigo.es

Received: 26/3/08 Accepted: 8/7/08

\begin{abstract}
Influence of iron and nitrate concentration in water on aquatic Coleoptera community structure: Application to the Avia river (Ourense, NW. Spain)

In this work the influence of the concentration of dissolved iron and nitrate in the water on the structure of the community of aquatic Coleoptera of a river in northwest Spain is analyzed. A total of 45 species and subspecies of aquatic Coleoptera (Adephaga and Polyphaga) were collected between March and November 1999 from 10 sites distributed along the Avia river (Ourense, N.W. Spain). Also, 24 physical and chemical parameters of water were measured and a CCA was made to evaluate which of these factors had the greatest influence on the studied fauna. At the same time an ecological analysis was made using the distribution of species and subspecies in relation to two water parameters (concentration of nitrate and dissolved iron). The study of distribution in relation to these factors by means of elaborating their ecological profiles suggested indicator species for each of these parameters. Seventeen species were found to be indicators for at least one of the parameters analyzed. The species Deronectes costipennis gignouxi, Enichocerus legionensis, Hydraena testacea, Megasternum obscurum, Nebrioporus depressus elegans and Stenelmis canaliculata are the best indicators of these parameters, if we consider only taxa collected in class 4 , that is, with high values of iron and nitrate.
\end{abstract}

Key words: Aquatic Coleoptera, dissolved iron, nitrate, indicator species, fluvial ecosystem.

\section{RESUMEN}

Influencia de la concentración de hierro y nitrato en el agua sobre la estructura de una comunidad de Coleoptera acuáticos: Aplicación al río Avia (Ourense, NO de España)

En este trabajo se analiza la influencia de la concentración de hierro disuelto y nitrato en el agua sobre la estructura de la comunidad de coleópteros acuáticos de un río en el noroeste de España. Un total de 45 especies y subespecies de Coleoptera acuáticos (Adephaga y Polyphaga) fueron recolectados entre marzo y noviembre de 1999 en 10 puntos distribuidos a lo largo del río Avia (Ourense, NW España). También se tomaron medidas de 24 de parámetros físicos y químicos del agua y se hizo un CCA para evaluar cuál de estos factores fue el de mayor influencia en la fauna estudiada. A partir de eso, realizamos un análisis ecológico de la distribución de la presencia de especies y subespecies en relación con dos factores químicos del agua (concentración de nitrato y hierro disuelto). El estudio de la distribución en relación con estos factores a través de la elaboración de sus perfiles ecológicos señaló las especies indicadoras para cada uno de estos parámetros, de acuerdo a su información recíproca de especie-factor. Diecisiete especies demostraron ser indicadoras de por lo menos unos de los parámetros analizados. Las especies Deronectes costipennis gignouxi, Enichocerus legionensis, Hydraena testacea, Megasternum obscurum, Nebrioporus depressus elegans y Stenelmis canaliculata son las mejores indicadoras de estos parámetros si tenemos en cuenta solo los taxones recogidos en la clase 4, es decir, con altos valores de hierro y nitrato.

Palabras clave: Coleoptera acuáticos, hierro disuelto, nitrato, especies indicadoras, ecosistema fluvial. 


\section{INTRODUCTION}

Fluvial ecosystems are of special interest because of their high biological richness and diversity. Communities of aquatic organisms have developed adaptations that allow them to prosper in these environments, which at the same time, make them very vulnerable to possible alterations in streams. In this sense, human activity often causes severe ecological damage to river systems. These disturbances produce alterations in the chemical composition of water, and in the structure of the communities of organisms living in this environment (Somolders et al., 1999; Smolders et al., 2003; Oller \& Goitia, 2005).

According to Nummelin et al. (2007) different groups of insects are excellent indicators of contamination by heavy metals. For Beasley \& Kneale (2003) macroinvertebrates, among them different groups of Coleoptera, are good indicators of high iron concentrations. A detailed study of the autoecology of different species of aquatic beetles shows that many of them have quite narrow ecological requirements and are very useful as bioindicators in determining the characteristics of aquatic environments (Castella et al., 1984; Flechtner, 1986; Davis et al., 1987; Foster et al., 1990; Foster et al., 1992; Eyre et al., 1992; Eyre et al., 1993; Collinson et al., 1995; Ribera et al. 1995a; Ribera et al. 1995b; Moreno et al., 1997). Other authors (Eyre \& Foster, 1989; Eyre \& Rushton, 1989) consider them as the most useful group in assessing environmental quality and change in static water. Brancucci (1980) and Ribera \& Foster (1992) state that beetles can be considered good indicators of macro and micro environmental characteristics of the aquatic environment in which they live.

Aquatic beetles are abundant in different freshwater habitats and show a high species richness of around 600 species and subspecies in the Iberian Peninsula (Ribera, 2000). In the first studies of water quality they remained very much in the background, but have now become more important as indicators (García-Criado \& Fernández-Aláez, 2001), since most of their life cycle occurs in aquatic environments. Jeffries (1988) shows that communities of aquatic beetles are a reflection of macroinvertebrate communities as a whole, and Heuss (1989) affirms that some Coleoptera can denote as many degrees of contamination as levels of dissolved oxygen. In the Iberian Peninsula, different studies on fluvial networks (García de Jalón \& González del Tánago, 1982; González del Tánago, 1986; González et al., 1986a; González et al., 1986b; Prat et al., 1983; Prat et al., 1984; Alba-Tercedor et al., 1986; Palau \& Palomes, 1986; Alba-Tercedor \& Jiménez, 1987; Cortés, 1989; Ribera \& Foster, 1992), point out Coleoptera within benthic communities as important bioindicators of pollution and evaluators of good water quality. In this sense the most abundant families in rivers are Hydraenidae and Elmidae, considered as the best indicators of environmental impacts (Díaz, 1991; García-Criado, 1999; García-Criado \& FernándezAláez, 1995; García-Criado \& Fernández-Aláez, 2001; García-Criado et al., 1999).

Different studies have used ecological profiles to designate indicator species (Petraglia \& Tomaselli, 2003; Bonada et. al. 2004; Mitov \& Stoyanov, 2005). There are different studies on the autoecology of several species of these Coleoptera (Puig 1983, Sáinz-Cantero et al., 1987; Sáinz-Cantero et al., 1988; Gil et al., 1990; Díaz ,1991; Garrido et al., 1994), and others that evaluate the sensitivity of many species to different ecological factors by ecological profile analysis and calculation of reciprocal information (Valladares et al., 1990; Garrido et al., 1994; García-Criado \& Fernández-Aláez, 1995). The study shows the preferences of several species of Coleoptera within the ranges of values found for several chemical factors of water.

\section{METHODS}

The study area is the Avia river in the south of the Galician Community, in the north-north west of Ourense Province, NW Spain (Fig. 1). It is surrounded by a set of massive mountain ranges forming the border with the provinces of Pontevedra and Lugo. Along its course it is fed by numerous streams forming a river of $643 \mathrm{Km}^{2}$ surface. The eastern part of the river flows on schistose substrate and mainly on 

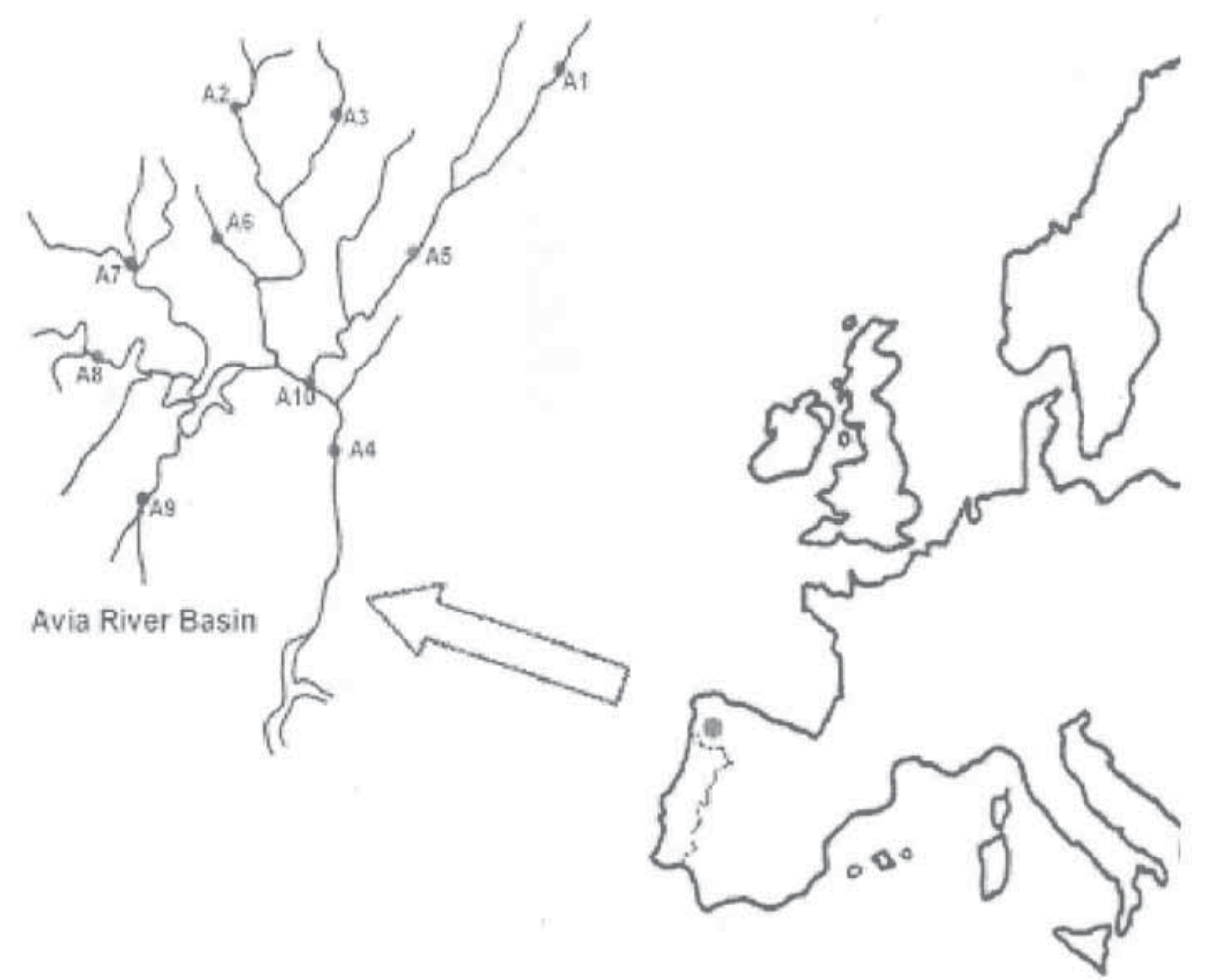

Figure 1. Location of the study area: Avia river with the sampling sites, in the Minho river basin. Localización del área de estudio: río Avia, con los puntos de muestreo, en la cuenca del rio Miño.

granite substrate in the west. The river Avia is located in the Miño river basin.

Samples were taken seasonally during an annual cycle (from March 1999 to November 1999) and were collected from ten sites (A1-A10) so we initially had forty samples designated with a code indicating the site $(\mathrm{Ax})$ and season (Wi, Sp, $\mathrm{Su}, \mathrm{Au}$ ) when the sample was taken. The samples were taken with an entomological water net (0.5 $\mu \mathrm{m}$ mesh), along $10 \mathrm{~m}$ for ten minutes. This is one of the more efficient methods of sampling to evaluate the specific diversity and structures of the community (García-Criado \& Trigal, 2005). Also, different physical and chemical parameters were measured, of which $\mathrm{pH}$, temperature, total dissolved salts (TDS), dissolved oxygen and conductivity were measured in situ.

Laboratory analysis of the water samples included tests for silica, phosphate, chlorine, ammonium, sulphate, nitrate, nitrite and the concentration of ions (including metals) dissolved in the water were obtained. The determination of trace elements was made with ICP-MS technique. The measured ions were: calcium, magnesium, sodium, potassium, iron, manganese, copper, chromium, aluminium, lead, zinc and cadmium. Some of the environmental variables did not surpass the detection limit, for example, chromium, cadmium, lead, zinc, phosphates and sulphates. These do not appear in the results (Table 1) and were not considered in this paper.

Canonical correspondence analysis (CCA) was used to analyse species-environment relationships (see Ter Braak \& Van Tongeren, 1995) in order to identify environmental (abiotic) factors potentially influencing aquatic Coleoptera assemblages. The factors analyzed were potassium, sodium, aluminium, manganese, iron and nitrate. The statistical significance of ordination axes 1 and 2 was determined using a Monte Carlo permutation test. Rare species (represented by just one individual) were not down-weighted thus 
Table 1. Physical and chemical variables measured in Avia river during period march- november, 1999. Means and ranges (minimum and maximum) values are represented. Variables físicas y químicas medidas en el río Avia durante el período marzo- noviembre de 1999. Valores medios y rangos (mínimo y máximo) son representados.

\begin{tabular}{|c|c|c|c|c|}
\hline \multirow[b]{2}{*}{ Parameter } & & \multicolumn{3}{|c|}{ Range } \\
\hline & & Mean & Maximum & Minimum \\
\hline Calcium & $\mathrm{mg} / \mathrm{l}$ & 0.65 & 2.08 & 0.17 \\
\hline Magnesium & $\mathrm{mg} / \mathrm{l}$ & 0.60 & 1.66 & 0.23 \\
\hline Potassium & $\mathrm{mg} / \mathrm{l}$ & 1.97 & 8.99 & 0.22 \\
\hline Sodium & $\mathrm{mg} / \mathrm{l}$ & 4.34 & 13.55 & 0.39 \\
\hline Manganese & $\mu \mathrm{g} / \mathrm{l}$ & 7.16 & 60.27 & 0.77 \\
\hline copper & $\mu \mathrm{g} / \mathrm{l}$ & 2.06 & 8.70 & $<0.5$ \\
\hline Iron & $\mu \mathrm{g} / \mathrm{l}$ & 57.56 & 484.33 & 4.56 \\
\hline Aluminium & $\mu \mathrm{g} / \mathrm{l}$ & 27.26 & 189.65 & 4.22 \\
\hline Silica & $\mathrm{mg} / \mathrm{l}$ & 2.19 & 7.40 & $<0.2$ \\
\hline Chlorine & $\mathrm{mg} / \mathrm{l}$ & 9.10 & 21.75 & $<5$ \\
\hline Amonium & $\mathrm{mg} / \mathrm{l}$ & 0.23 & 0.45 & $<0.05$ \\
\hline Nitrite & $\mathrm{mg} / \mathrm{l}$ & 0.14 & 0.28 & $<0.01$ \\
\hline Nitrate & $\mathrm{mg} / \mathrm{l}$ & 5.39 & 11.20 & $<2.2$ \\
\hline Temperature & ${ }^{\circ} \mathrm{C}$ & 11.92 & 19.40 & 7.43 \\
\hline $\mathrm{pH}$ & & 6.92 & 8.17 & 6.13 \\
\hline Conductivity & $\mu \mathrm{S} / \mathrm{cm}$ & 36.71 & 76.70 & 19.6 \\
\hline $\mathrm{O}_{2}$ & $\mathrm{mg} / \mathrm{l}$ & 9.69 & 12.16 & 7.07 \\
\hline $\mathrm{O}_{2}$ & $\%$ & 94.64 & 111.00 & 76.3 \\
\hline TDS & $\mathrm{mg} / \mathrm{l}$ & 15.25 & 34.00 & 9.00 \\
\hline
\end{tabular}

all occurrences were included in the analysis. The data for the ecological profiles were analysed as follows: firstly, the observed range of values for each habitat parameter was divided into a series of intervals, as homogeneously as possible. The samples were assigned according to the values obtained for each parameter, thus enabling us to determine the number of samples in the different classes. The expression of Daget, Godron \& Guillerm (1972) was used to determine water quality.

First the data was shown in the form of an absolute frequency profile (number of presences of each species in each class of the parameter). However, the total number of samples included in each class of parameter had to be considered, as well as the frequency of each species in the set of samples. This way, differences between the features of rare and frequent species were corrected. For this reason, we presented the profile of corrected frequencies that considered the relative average frequency of presences. The values of this profile were calculated using the expression of Daget \& Godron (1982). We then determined which of the studied species were more closely linked to the different factors, both positively and negatively, and which could be considered as indicators, thus allowing the analysis to be continued with a smaller group of species. The information provided by a species in relation to the different factors was estimated from the ecological features of presence and absence, named "Reciprocal information" and was taken as a measure of the indicator value of the species in relation to the physicochemical parameters considered. For a species $\mathrm{E}$ and iron levels $\mathrm{L}$, such information is expressed as I (L; E) and defined from the expression mentioned in Godron (1968). Finally, to summarise the information given by each profile in a single value we calculated barycentre "G". This can be taken as a measurement of the optimum ecological degree of the species. The expression used for this calculation is mentioned in Daget \& Godron, 1982.

\section{RESULTS}

A total of 6250 specimens of aquatic Coleoptera, belonging to 45 taxa, were identified in 10 sampling sites in the Avia river, all of which are listed 
Table 2. Total species studied in Avia river (march-november, 1999) and respective values of corrected frequencies, mutual information and barycentres. Total de especies estudiadas en el río Avia (marzo-noviembre, 1999) y respectivos valores de frecuencias corregidas, información mutua y baricentro.

\begin{tabular}{|c|c|c|c|c|c|c|c|c|c|c|c|c|}
\hline \multirow[b]{3}{*}{ Species } & \multicolumn{6}{|c|}{ Dissolved Iron } & \multicolumn{6}{|c|}{ Nitrate } \\
\hline & \multicolumn{4}{|c|}{ Corrected frequencies } & \multirow[t]{2}{*}{ Mutual inf } & \multirow[t]{2}{*}{ Barycentre } & \multicolumn{4}{|c|}{ Corrected frequencies } & \multirow[t]{2}{*}{ Mutual inf } & \multirow[t]{2}{*}{ Barycentre } \\
\hline & $\mathrm{C} 1$ & $\mathrm{C} 2$ & C 3 & $\mathrm{C} 4$ & & & $\mathrm{C} 1$ & $\mathrm{C} 2$ & C 3 & $\mathrm{C} 4$ & & \\
\hline Haliplidae & & & & & & & & & & & & \\
\hline $\begin{array}{l}\text { Haliplus lineatocollis } \\
\text { Dytiscidae }\end{array}$ & 0 & 2.571 & 0 & 0 & 0.039 & 2 & 2.571 & 0 & 0 & 0 & 0.039 & 1 \\
\hline Deronectes costipennis gignouxi & 0 & 2.571 & 0 & 0 & 0.039 & 2 & 0 & 0 & 0 & 7.2 & 0.083 & 4 \\
\hline Deronectes ferrugineus & 0 & 2.571 & 0 & 0 & 0.079 & 2 & 0 & 0 & 2.571 & 3.6 & 0.094 & 3.583 \\
\hline Graptodytes fractus & 0 & 2.571 & 0 & 0 & 0.039 & 2 & 0 & 0 & 5.143 & 0 & 0.068 & 3 \\
\hline Graptodytes ignotus & 0 & 1.714 & 1.714 & 0 & 0.069 & 2.5 & 0.857 & 1.2 & 1.714 & 0 & 0.024 & 2.227 \\
\hline Hydroporus nigrita & 0 & 0 & 2.571 & 4.5 & 0.104 & 3.636 & 0 & 1.8 & 0 & 3.6 & 0.079 & 3.333 \\
\hline Nebrioporus depressus elegans & 0 & 0 & 0 & 9 & 0.093 & 4 & 0 & 0 & 5.143 & 0 & 0.068 & 3 \\
\hline Nebrioporus carinatus & 0.818 & 1.285 & 0 & 2.25 & 0.049 & 2.846 & 0 & 0.9 & 2.571 & 1.8 & 0.106 & 3.171 \\
\hline Oreodytes sanmarkii alienus & 0 & 2.571 & 0 & 0 & 0.039 & 2 & 0 & 0 & 5.143 & 0 & 0.068 & 3 \\
\hline Stictonectes epipleuricus & 1.454 & 1.142 & 0.571 & 0 & 0.072 & 1.721 & 0.857 & 2 & 0.571 & 0 & 0.127 & 1.917 \\
\hline Stictonectes lepidus & 0 & 2.571 & 0 & 0 & 0.122 & 2 & 0 & 1.2 & 1.714 & 2.4 & 0.068 & 3.226 \\
\hline $\begin{array}{l}\text { Stictotarsus bertrandi } \\
\text { Hydrophilidae }\end{array}$ & 1.227 & 1.285 & 0.642 & 0 & 0.055 & 1.815 & 0.321 & 2.25 & 1.286 & 0 & 0.174 & 2.25 \\
\hline Anacaena globulus & 1.09 & 1.285 & 0.857 & 0 & 0.034 & 1.928 & 0.429 & 1.2 & 2.571 & 0 & 0.114 & 2.51 \\
\hline $\begin{array}{l}\text { Megasternum obscurum } \\
\text { Hydrochidae }\end{array}$ & 0 & 0 & 0 & 9 & 0.093 & 4 & 0 & 0 & 0 & 7.2 & 0.083 & 4 \\
\hline $\begin{array}{l}\text { Hydrochus angustatus } \\
\text { Helophoridae }\end{array}$ & 0 & 2.571 & 0 & 0 & 0.079 & 2 & 0 & 0 & 2.571 & 3.6 & 0.093 & 3.583 \\
\hline $\begin{array}{l}\text { Helophorus flavipes } \\
\text { Hydraenidae }\end{array}$ & 3.272 & 0 & 0 & 0 & 0.049 & 1 & 0 & 3.6 & 0 & 0 & 0.051 & 2 \\
\hline Enichocerus legionensis & 0 & 2.571 & 0 & 0 & 0.039 & 2 & 0 & 0 & 0 & 7.2 & 0.083 & 4 \\
\hline Hydraena barrosi & 1.636 & 1.285 & 0 & 0 & 0.1 & 1.44 & 0.429 & 0.6 & 3.429 & 0 & 0.184 & 2.673 \\
\hline Hydraena brachymera & 0.909 & 1.142 & 0.857 & 1 & 0.01 & 2.498 & 0.714 & 1 & 1.714 & 0.8 & 0.11 & 2.615 \\
\hline Hydraena corinna & 1.309 & 0.514 & 2.057 & 0 & 0.06 & 2.193 & 1.543 & 0.72 & 1.029 & 0 & 0.044 & 1.844 \\
\hline Hydraena hispanica & 1.006 & 1.384 & 0.791 & 0 & 0.098 & 1.932 & 0.791 & 0.554 & 2.374 & 0.554 & 0.19 & 2.63 \\
\hline Hydraena iberica & 1.5 & 0.964 & 0.428 & 0.75 & 0.274 & 2.118 & 0.75 & 1.35 & 1.286 & 0.6 & 0.149 & 2.435 \\
\hline Hydraena inapicipalpis & 2.013 & 0.395 & 1.186 & 0 & 0.264 & 1.77 & 0.198 & 1.938 & 1.582 & 0.554 & 0.263 & 2.583 \\
\hline Hydraena lusitana & 1.636 & 1.071 & 0.428 & 0 & 0.134 & 1.615 & 0.857 & 1.5 & 1.286 & 0 & 0.101 & 2.118 \\
\hline Hydraena sharpi & 1.402 & 1.102 & 0.734 & 0 & 0.109 & 1.794 & 0.989 & 1.385 & 1.187 & 0 & 0.1 & 2.056 \\
\hline Hydraena stussineri & 1.963 & 1.028 & 0 & 0 & 0.093 & 1.344 & 0.514 & 0.72 & 3.086 & 0 & 0.115 & 2.595 \\
\hline Hydraena testacea & 0 & 0 & 0 & 9 & 0.093 & 4 & 0 & 0 & 0 & 7.2 & 0.083 & 4 \\
\hline $\begin{array}{l}\text { Hydraena unca } \\
\text { Elmidae }\end{array}$ & 0 & 0 & 5.142 & 0 & 0.068 & 3 & 0 & 3.6 & 0 & 0 & 0.051 & 2 \\
\hline Dupophilus brevis & 0.818 & 1.028 & 1.028 & 1.35 & 0.022 & 2.689 & 0.771 & 0.9 & 1.8 & 0.72 & 0.195 & 2.589 \\
\hline Elmis aenea & 0.654 & 1.028 & 1.371 & 1.2 & 0.036 & 2.733 & 0.857 & 1.2 & 1.029 & 0.96 & 0.008 & 2.517 \\
\hline Elmis maugetii maugetii & 1.272 & 1.142 & 0.857 & 0 & 0.136 & 1.873 & 0.857 & 1 & 1.429 & 0.8 & 0.036 & 2.531 \\
\hline Elmis perezi & 2.181 & 0.857 & 0 & 0 & 0.06 & 1.282 & 0 & 1.2 & 3.429 & 0 & 0.118 & 2.741 \\
\hline Elmis rioloides & 0.872 & 1.2 & 1.028 & 0.6 & 0.02 & 2.366 & 0.857 & 1.2 & 0.686 & 1.44 & 0.034 & 2.648 \\
\hline Esolus angustatus & 1.227 & 1.607 & 0 & 0 & 0.14 & 1.567 & 0.964 & 0.9 & 1.929 & 0 & 0.081 & 2.254 \\
\hline Esolus parallelepipedus & 1.033 & 1.218 & 0.812 & 0.473 & 0.047 & 2.205 & 0.947 & 0.758 & 1.353 & 1.137 & 0.029 & 2.639 \\
\hline Limnius opacus & 1.309 & 0.514 & 0 & 3.6 & 0.117 & 3.086 & 1.029 & 0 & 2.057 & 1.44 & 0.077 & 2.864 \\
\hline Limnius perrisi carinatus & 1.09 & 1.142 & 0.857 & 0.5 & 0.031 & 2.213 & 1 & 1.2 & 1.429 & 0 & 0.174 & 2.118 \\
\hline Limnius volckmari & 0.981 & 0.514 & 1.542 & 1.8 & 0.061 & 2.86 & 0.771 & 1.08 & 1.543 & 0.72 & 0.024 & 2.538 \\
\hline Normandia nitens & 0 & 1.285 & 0 & 4.5 & 0.075 & 3.556 & 0 & 0 & 5.143 & 0 & 0.143 & 3 \\
\hline Oulimnius bertrandi & 1.09 & 1.142 & 0.761 & 0.666 & 0.069 & 2.274 & 0.762 & 1.333 & 1.143 & 0.8 & 0.062 & 2.491 \\
\hline Oulimnius troglodytes & 0 & 0.964 & 1.928 & 2.25 & 0.17 & 3.25 & 1.286 & 0 & 0.643 & 2.7 & 0.179 & 3.028 \\
\hline Oulimnius tuberculatus perezi & 1.09 & 1.428 & 0.571 & 0 & 0.072 & 1.832 & 0.857 & 0.8 & 1.714 & 0.8 & 0.027 & 2.589 \\
\hline $\begin{array}{l}\text { Stenelmis canaliculata } \\
\text { Dryopidae }\end{array}$ & 0 & 0 & 0 & 9 & 0.093 & 4 & 0 & 0 & 0 & 7.2 & 0.083 & 4 \\
\hline Dryops luridus & 0 & 0.857 & 3.428 & 0 & 0.102 & 2.8 & 1.714 & 1.2 & 0 & 0 & 0.054 & 1.412 \\
\hline
\end{tabular}


in Table 2. Also, 24 physical and chemical variables were measured; five of them gave results below the detection limits and are not included in this analysis (Table 1).

According to the CCA the most significant axis is 1 , with a significance of 0.362 . The parameters were very significantly correlated ( $r=0.91$ between iron and manganese; $r=0.49$ between manganese and nitrate; $r=0.44$ between iron and nitrate) and also showed high correlation with Axis 1 (iron: $r=0.61$; manganese: $r=0.39$; nitrate: 0.31$)$. The canonical correspondence analysis showed that the majority of species responded negatively to iron, nitrate and manganese (Fig. 2). However, the joint CCA of species clearly separated a subset of five aquatic beetle species along the iron environmental axis (Hydraena testacea, Megasternum obscurum, Stenelmis canaliculata,
Nebrioporus depressus elegans and Oulimnius troglodytes), two species along the nitrate axis (Enicocerus legionensis and Deronectes costipennis gignouxi) and only one species (Hydroporus nigrita) along the manganese axis (Fig. 2). After making a multivariate analysis we selected two variables with significant values and variations that could influence the distribution or location of the species, these factors were concentration of dissolved iron and nitrates in the water. The CCA indicates that the manganese concentration is one of the most significant elements in these rivers. However, ecological profiles were not made as there was no significant correlation with any of the species (corrected frequency high and barycentre above 2). According to Nummelin et al. (2007) the best bioindicators of this metal are water striders and not water beetles.

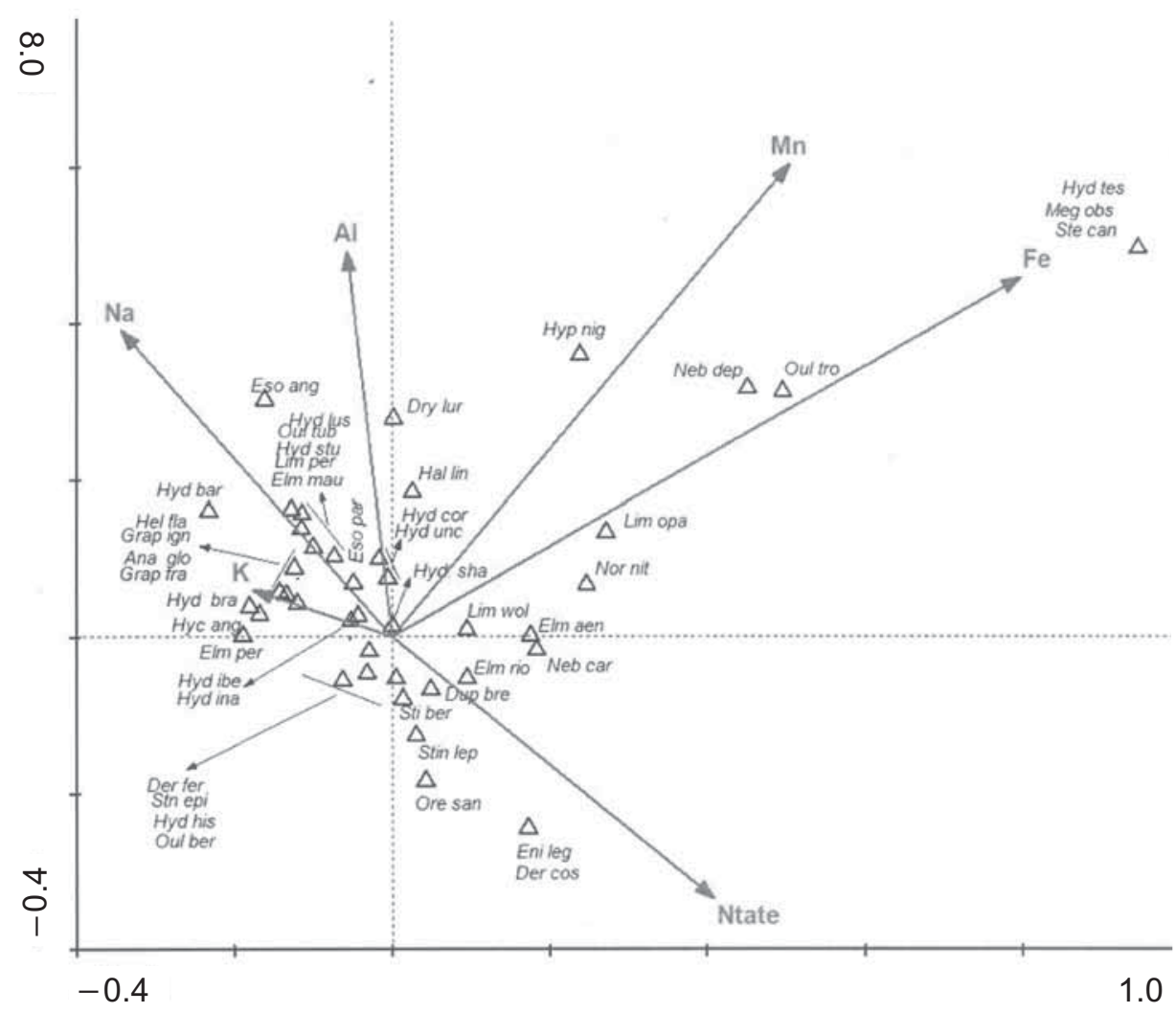

Figure 2. Canonical Correspondence Analysis (CCA) based on the water beetles species in the Avia river. Análisis de Correspondencias Canónicas (CCA) basado en las especies de escarabajos acuáticos en el río Avia. 
a) Hydraena testacea

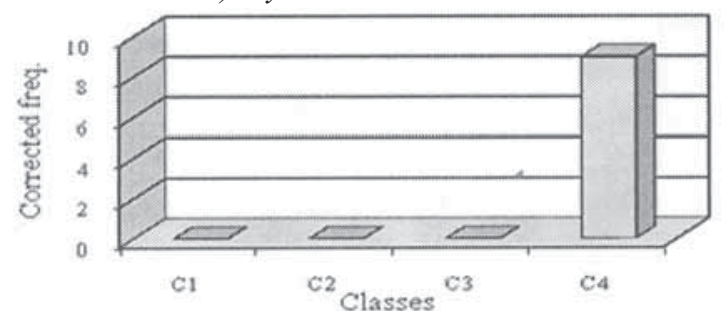

c) Hydroporus nigrita

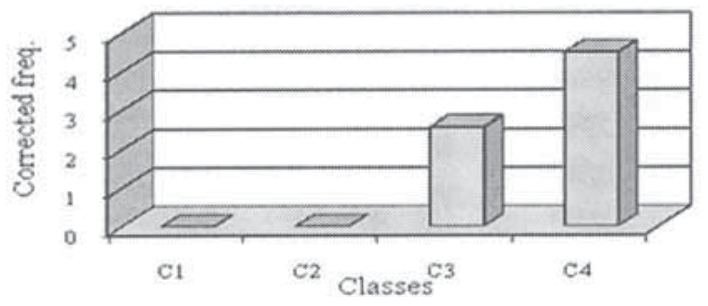

e) Megasternum obscurum

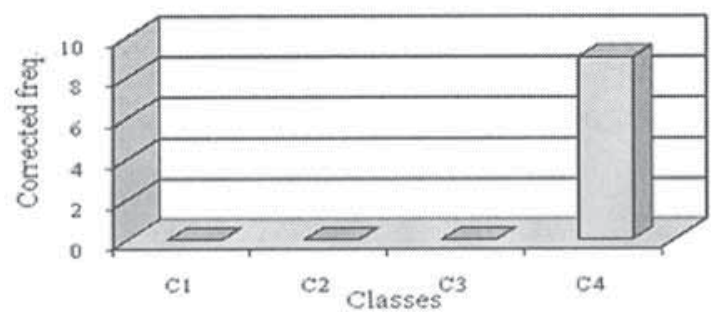

g) Normandia nitens

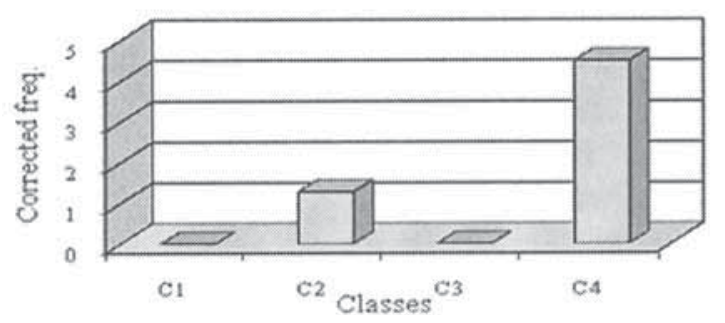

i) Stenelmis canaliculata

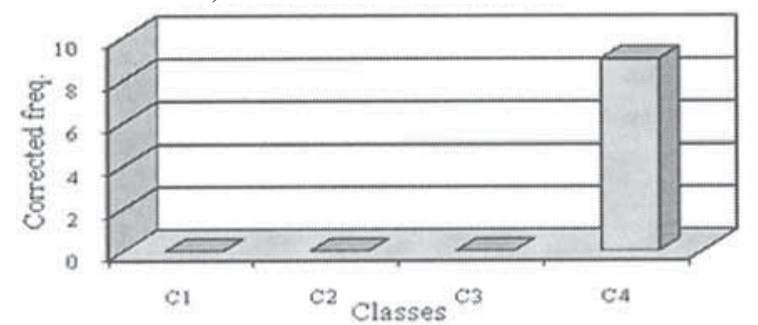

b) Hydraena unca

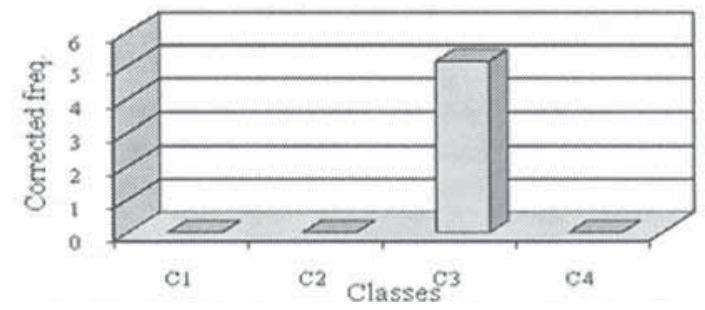

d) Limnius opacus

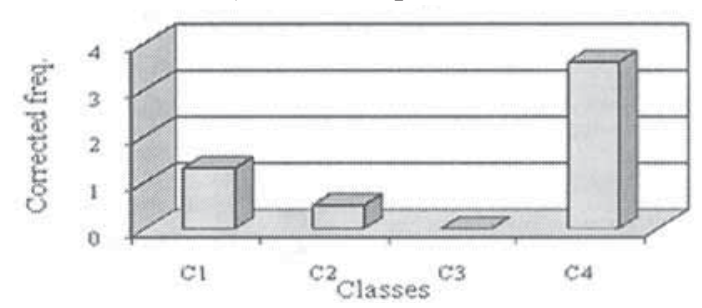

f) Nebrioporus depressus elegans

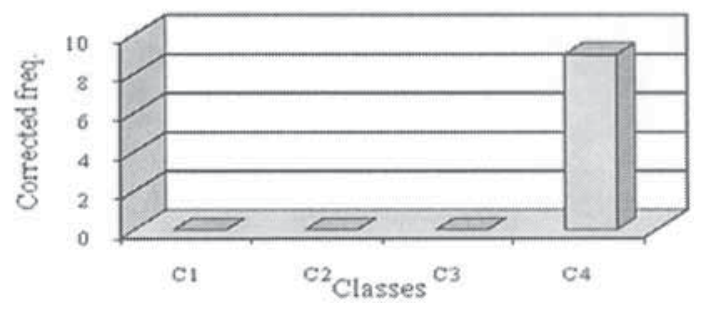

h) Oulimnius troglodytes

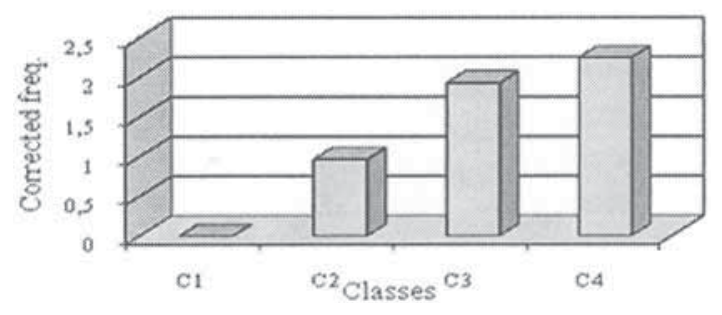

Figure 3. (a-i) Ecological profiles for the species from sites with a high concentration of dissolved iron. (a-i) Perfiles ecológicos de las especies de los puntos con una concentración alta de hierro disuelto. 
a) Deronectes costipennis gignouxi

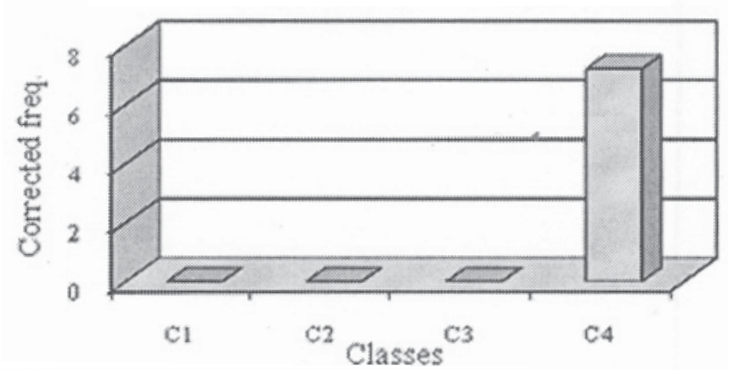

c) Enichocerus legionensis

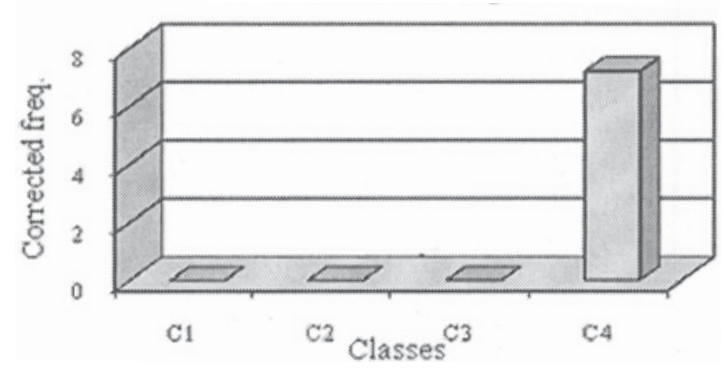

e) Hydraena testacea

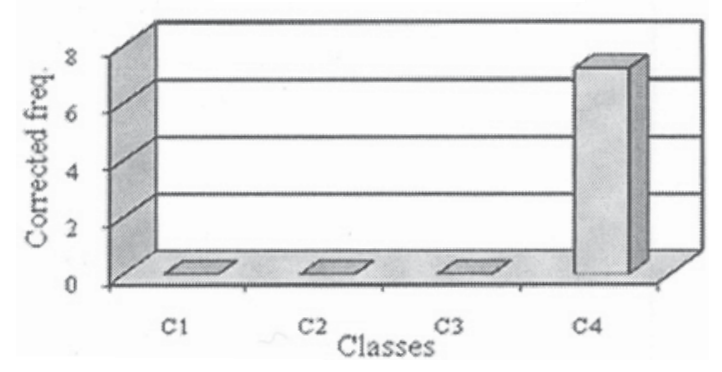

g) Hydroporus nigrita

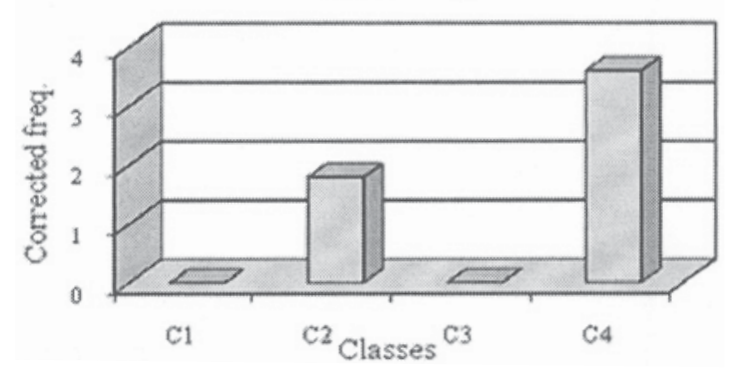

b) Deronectes ferrugineus

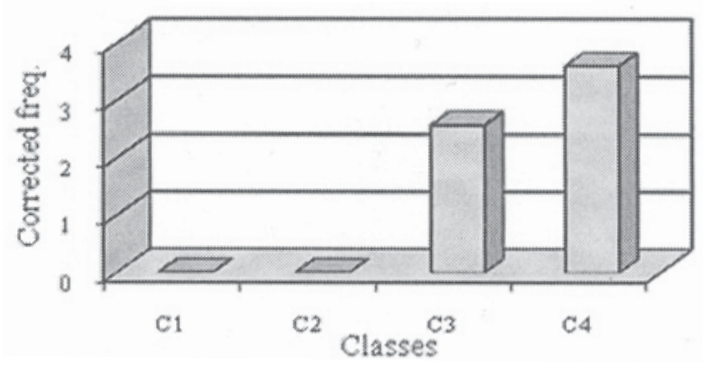

d) Graptodytes fractus

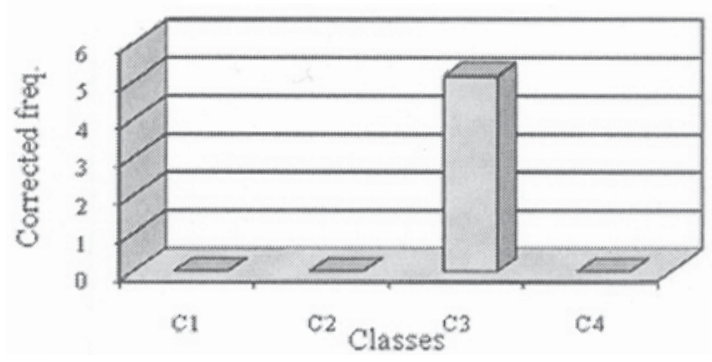

f) Hydrochus angustatus

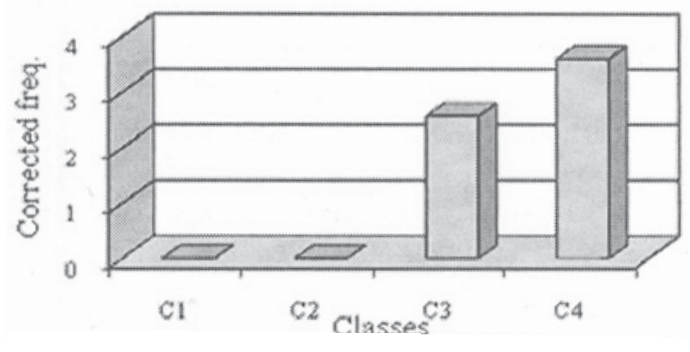

h) Megasternum obscurum

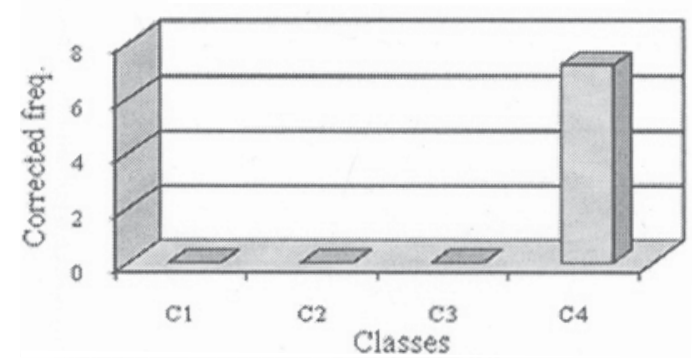

Figure 4. (a-o) Ecological profiles for the species from sites with high concentration of nitrate. (a-o) Perfiles ecológicos de las especies de los puntos con una concentración alta de nitrato. 
i) Nebrioporus carinatus

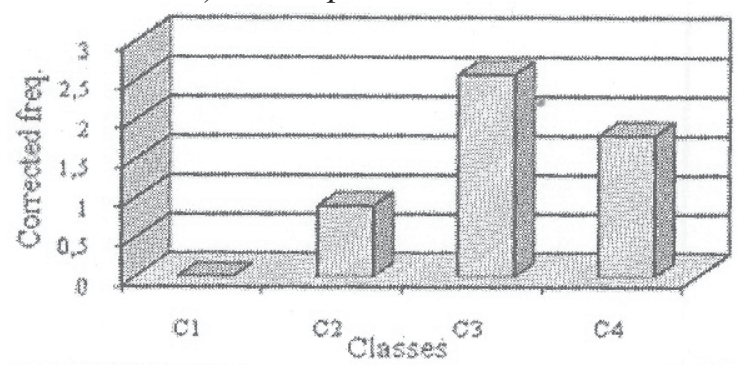

k) Normandia nitens

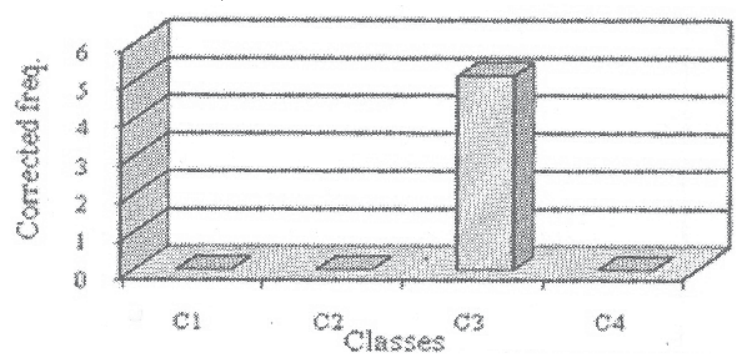

m) Oulimnius troglodytes

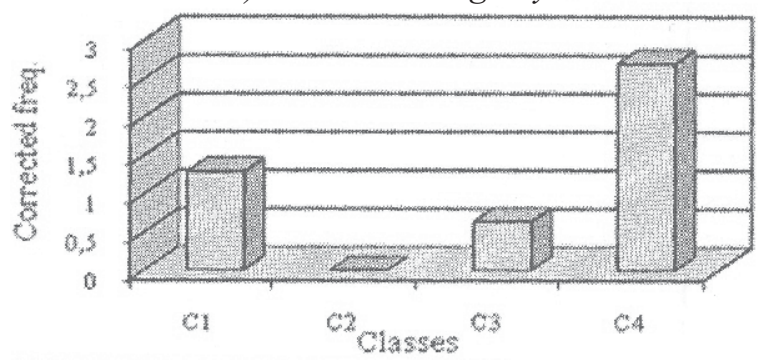

o) Stictonectes lepidus

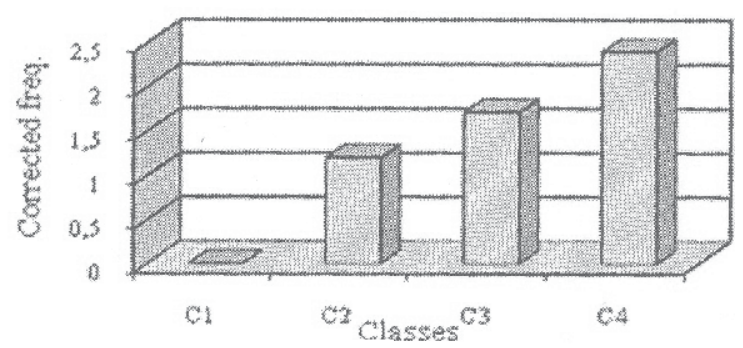

Figure 4. (continuation)
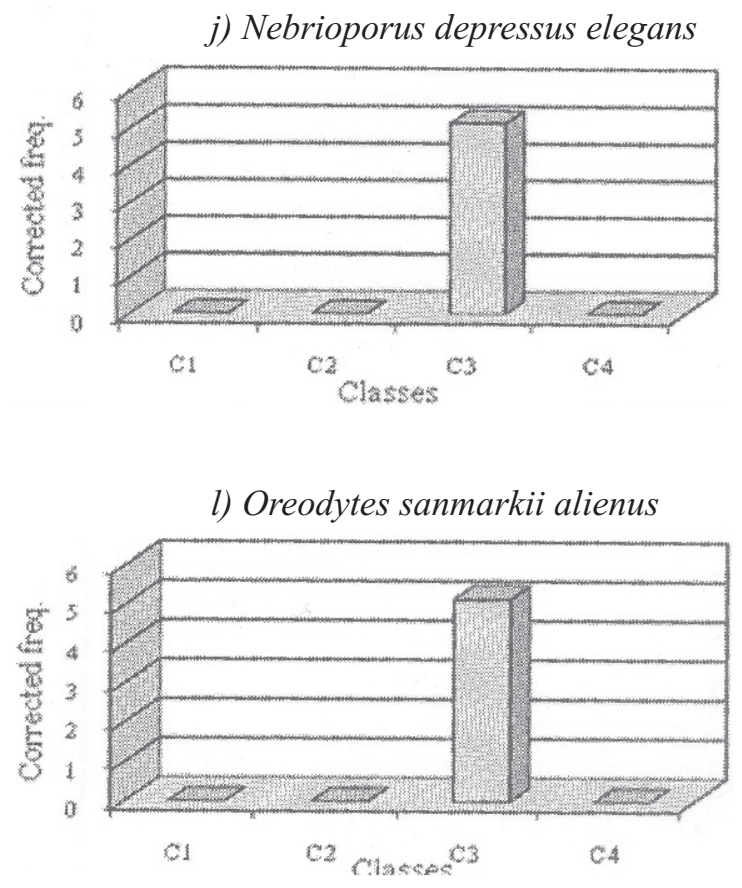

n) Stenelmis canaliculata

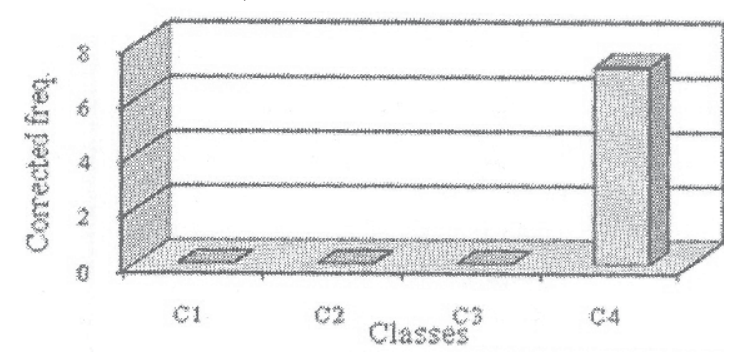


The results of the ecological profiles appear in Table 2 and show the corrected frequencies and indicator value for each species (reciprocal species-describer information) and the barycentre for each of the two variables studied. With regard to species preferences for dissolved iron and nitrate concentrations, we only consider the species with high reciprocal information values for each parameter and barycentre equal to 4, (Figs. 3 and 4). The response of the species most closely linked (those giving more information) to each of the surveyed variables is shown below:

Iron: The observed sampling quality value for this variable was 0.932 , which is quite high, indicating that it was sufficiently sampled. The range of values for this parameter $(4.56-484.3 \mu \mathrm{g} / \mathrm{l})$ was divided into four intervals (C1: less $25 \mu \mathrm{g} / \mathrm{l}$; C2: 25-49.9 $\mu \mathrm{g} / \mathrm{l}$; C3: 50-74.9 $\mu \mathrm{g} / \mathrm{l}$; C4: more $75 \mu \mathrm{g} / \mathrm{l})$, depending on the number of the samples. Thus, the last interval was more extensive due to the low number of samples. The most representative species for this variable (barycentre equal or superior to 3) are indicated in figure 3. These species are characteristic of sites with a high concentration of dissolved iron and were found fundamentally in classes 3 and 4 .

Nitrate: A sampling quality value of 0.949 , higher than that for iron, was obtained, indicating that it was also sufficiently sampled. The nitrate values were between 2.2-11.2 mg/l. Due to the existence of a great number of samples below the detection limit, the interval $<2.2 \mathrm{mg} / \mathrm{l}$ was created to include those samples with very low nitrates values. So this range was divided into four intervals (C1: less $2.2 \mathrm{mg} / \mathrm{l}$; $\mathrm{C} 2$ : 2.2-5.29 mg/l; C3: 5.30-6.49 mg/l; C4: more $6.5 \mathrm{mg} / \mathrm{l}$ ), was well as iron, depending on the number of the samples. According to their profiles of distribution in these intervals, the most representative species for this variable (barycentre equal or superior to 3) are indicated in figure 4 . As in the case of iron, we can also state that, for nitrate, these species are characteristic of sites with high concentrations of nitrate and were found fundamentally in classes 3 and 4 .

\section{DISCUSSION}

The results obtained in this paper contribute data to the study of the autoecology of species and to how physical and chemical variables of the environment influence the habitats and distribution of aquatic Coleoptera. In order to reach final conclusions on the ecological preferences of each species, the effect of polluting agents and tolerance to their different levels, more studies in other rivers are necessary. The objective of this study was to verify whether iron and nitrate influence the distribution of species of aquatic Coleoptera and result in the establishment of communities more or less tolerant to high concentrations of these variables. We have to consider that many other local characteristics can also influence the distribution of the species in greater or smaller measure.

When interpreting the results, it should be taken into account that in this river the high concentrations of iron and nitrate, produced by discharge of fertilizers and industrial waste, were localized, so it was difficult to distinguish whether the distribution of a certain taxa depended on the chemical characteristics of the water. Also, we must not forget that this research only deals with lotic environments. Therefore, specimens peculiar to lenthic habitats, such as Hydraena testacea, have different ecological preferences in lenthic sites.

Of all 45 species and subspecies collected, 17 proved to be indicators for at least one of the parameters analyzed and collected in classes 3 and 4 (Figs. 3 and 4). This number is reduced to 6 if we consider only taxa collected in class 4 , which are the best indicators of these parameters. The 6 species are: Deronectes costipennis gignouxi, Enichocerus legionensis, Hydraena testacea, Megasternum obscurum, Nebrioporus depressus elegans and Stenelmis canaliculata. These taxa are likewise ones with the greatest average indicator value, thus giving more global information about the variables under consideration.

With regard to the values for iron in the group of species found in areas with high concentrations, we observed differences when compared with results obtained by other authors. This is the 
case of Hydraena testacea which, in this study, was collected in areas with high iron concentrations, in contrast to data provided by Díaz (1991) in the Landro river (Lugo, NW Spain), in a study on the Hydraenidae family. In the study carried out by Paz (1993) on Adephaga, in the same river, Hydroporus nigrita was found in practically all the samplings sites, with both high and low iron concentrations. However, in our study it was mainly found close to high concentrations of this metal. Differences with Díaz (1991) and Paz (1993) are due to the low concentrations of these parameters in the Landro river and therefore the analyzed species were not indicators in these studies.

Another species found exclusively in sites with high iron values was Nebrioporus depressus elegans. There is no significant information on this species in other works, though Lorenz (2004) indicates that it is a negative indicator for freshwaters in Germany. There is little information available in other studies on the relation between the studied species and iron. Therefore, the results obtained here do not have a comparison point and should be considered with precaution when stating that these species are indicators of iron in freshwater bodies. Extensive literature supports the fact that high iron concentrations have a negative effect on the fauna of aquatic ecosystems (Blasco et al., 1999; Blasco et al., 2000), something also stated in our study, since most of the studied species do not occur in sites with high concentrations of this metal. According to Beasley and Kneale (2003) species of Coleoptera, specially Hydrophilidae and Dytiscidae, are the best bioindicators of iron in aquatic systems, agreeing with the results obtained in our study, though we have also indicated species of Hydraenidae and Elmidae as excellent indicators of this metal. (Fig. 2).

In the case of the second parameter, nitrate, we found that the studied species have antagonistic behaviours in other studies. Thus, Enicocerus legionensis is classified in our study as being distributed in areas of high concentration, in contrast to Díaz (1991) who, in a study in the Landro river (Lugo, NW Spain), states that it is sensitive to organic contamination as it was only pre- sent in two sampling sites with very clean water. However García-Criado (1999) found the species in sites affected by coal mining in León (Spain), which could be indicative of tolerance to contamination. As in the case of iron, we do not have extensive comparative data for nitrate and therefore cannot affirm that these species are indicative of high nitrate levels, although the collected data are a strong indication of this relation in the studied rivers. According to different authors (Blasco et al., 2000; Ortiz et al., 2005) high nitrate concentrations in the water make the survival of many species difficult, in benefit of other opportunist species that are more tolerant to this chemical parameter. This was also detected by Oliveira \& Cortes (2005) who emphasize the importance of measuring nitrate concentrations to evaluate fluvial systems correctly. In our work only a few species were tolerant to high nitrate values and the same occurred with iron, indicating possible contamination in certain sites.

It should be pointed out that iron and nitrate occur naturally in fluvial systems, though high levels could indicate localized pollution. The levels in the Avia river were not excessively high, however, both of them showed peaks that may be indicative of a certain level of pollution. The peaks observed in the points A5 and A10 in spring and summer and are due to discharge of fertilizers (agricultural areas) or industrial waste (light industries).

The CCA analysis, corroborated by barycentre values, shows clearly and briefly what we have discussed so far. Deronectes costipennis gignouxi and Enichocerus legionensis stand out because of their tolerance to relatively high levels of nitrate. Oreodytes sanmarkii alienus and Stictonectes lepidus exhibit more intermediate positions, though also a certain degree of tolerance. Hydraena testacea, Megasternum obscurum and Stenelmis canaliculata stand out because of their tolerance to high levels of dissolved iron. Nebrioporus depressus elegans and Oulimnius troglodytes exhibit more intermediate positions, but also show a high degree of tolerance. At the opposite end are most of the studied species, present at sites with low values for both analysed parameters. According to the ecological profiles of 
the studied species in relation to their response to the analysed parameters (iron and nitrate) it can be stated that three of them (Hydraena testacea, Megasternum obscurum and Stenelmis canaliculata) were found exclusively in sites with high concentrations of both iron and nitrate. This could indicate that they are tolerant species, though also opportunist, since they occupy the place of other more sensitive and less tolerant species not found in these sites.

\section{REFERENCES}

ALBA-TERCEDOR, J. y F. JIMÉNEZ-MILLÁN. 1987. Evaluación de las variaciones estacionales de la calidad de las aguas del río Guadalfeo basada en el estudio de las comunidades de macroinvertebrados acuáticos y de los factores físicoquímicos. Proyecto Lucdeme III, ICONA. Madrid. $174 \mathrm{pp}$.

ALBA-TERCEDOR, J., I. GUISASOLA y A. SÁNCHEZ-ORTEGA. 1986. Variaciones estacionales de las características físico-químicas y de la calidad biológica de las aguas del R. Guadalfeo (Granada). In: El agua en Andalucía, I. Universidad de Granada (ed.): 235-247. Universidad de Granada, Granada.

BEASLEY, G. \& P. KNEALE. 2003. Investigating the influence of heavy metals on macroinvertebrate assemblages using Partial Canonical Correspondence Analysis. Hydrobiology and Earth System Sciences, 7: 221-233.

BLASCO, J., A. M. ARIAS \& V. SÁENZ. 1999. Heavy metals in organisms of the River Guadalquivir estuary: possible incident of the Aznalcóllar disaster. Sci. Total Environ., 242: 249-259.

BLASCO, J., V. SÁENZ \& A. GÓMEZ-PARRA. 2000. Heavy metal fluxes at the sediment-water interface of three coastal ecosystems from southwest of the Iberian Peninsula. Sci. Total Environ., 247: 189-199.

BONADA, N., C. ZAMORA-MUÑOZ, M. RIERADEVALL \& N. PRAT. 2004. Ecological profiles of caddisfly larvae in Mediterranean streams: implications for bioassessment methods. Environmental Pollution, 132: 509-521.

BRANCUCCI, M. 1980. Observations on the ecology of the Dytiscidae (Coleoptera) in the water system connected to the south coast of Neuchatel lake (Switzerland). Mitteilungen der Schweizerischen Entomologischen Gesellschaft, 53: 365-378.

CASTELlA, E., M. RICHARDOT-COULE, C. ROUX \& P. RICHOUX. 1984. Macroinvertebrates as "describers" of morphological and hydrological types of aquatic ecosystems abandoned by Rhone River. Hydrobiologia, 119: 219-225.

COLLINSON, N. H., J. BIGGS., A. CORFIELD., M. J. HODSON., D. WALKER., M. WHITFIELD \& P. J. WILLIAMS. 1995. Temporary and permanent ponds: An assessment of the effects of drying out on the conservation value of aquatic macroinvertebrate communities. Biological Conservation, 74: 125-133.

CORTÉS, R. M. V. 1989. Biotipología de ecosistemas lóticos do Nordeste de Portugal. Ph.D. Thesis, Universidad de Tras os Montes e Alto Douro, Vila Real, Portugal, 305 pp.

DAGET, P. et M. GODRON. 1982. Analyse fréquentielle de l'Écologie des espèces dans les communautés. Coll. d'Écologie. Masson, París, 163 pp.

DAGET, P., M. GODRON et J. M. GUILLERM. 1972. Profils écologiques et information mutuelle entre espèces et facteurs écologiques. In: Grundfragen und Methoden in der Pflanzensoziologie. Van der Maarel (ed.): 191-202. La Haya.

DAVIS, J. A., S. W. ROLLS \& S. A. BALLA. 1987. The role of the Odonata and aquatic Coleoptera as indicators of environmental quality in wetlands. In: The Role of Invertebrates in Conservation and Biological Survey. Majer, J. D. (ed.): 31-42. Western Australian Department of Conservation and Land Management Report.

DÍAZ, J. A. 1991. Estudio taxonómico y ecológico de los Hydraenidae (Coleoptera) de la cuenca del río Landro (Lugo, España). Ph.D. Thesis. Universidad de Santiago de Compostela. 515 pp.

EYRE, M. D. \& G. N. FOSTER. 1989. A comparison of aquatic Heteroptera and Coleoptera communities as a basis for environmental and conservation assessments in static water sites. Journal Applied Entomology, 108: 355-362.

EYRE, M. D. \& S. P. RUSHTON. 1989. Quantification of conservation criteria using invertebrates. Journal of Applied Ecology, 26: 159-171.

EYRE, M. D., G. N. FOSTER \& A. G. YOUNG. 1993. Relationships between water-beetle distributions and climatic variables: A possible index for monitoring global climatic change. Arch. Hydrobiol., 127: 437-450. 
EYRE, M. D., R. CARR, R. P. MCBLANE \& G. N. FOSTER. 1992. The effects of varying site-water duration on the distribution of water beetle assemblages, adults and larvae (Coleoptera: Haliplidae, Dytiscidae, Hydrophilidae). Arch. Hydrobiol., 124: 281-291.

FLECHTNER, G. 1986. Association analysis of water-beetles communities (Coleoptera, Dytiscidae et Haliplidae). Entomologica Basiliensia, 11: 297-308.

FOSTER, G. N., A. P. FOSTER., M. D. EYRE \& D.T. BILTON. 1990. Classification of water beetles assemblages in arable fenland and ranking of sites in relation to conservation value. Freshwat. Biol., 22: 343-354.

FOSTER, G. N., B. H. NELSON., D. T. BILTON., D. A. LOTT., R. MERRIT, R. S. WEYL \& M. D. EYRE. 1992. A classification and evaluation of Irish water beetle assemblages. Aquatic Conservation: Marine and Freshwater Ecosystems, 2: 185-208.

GARCÍA-CRIADO, F. 1999. Impacto de la minería del carbón sobre Hydraenidae y Elmidae (Coleoptera) en la cuenca del río Sil (León, España). Ph.D. Thesis. Universidad de León, 281 pp.

GARCÍA-CRIADO,F. \& M. FERNÁNDEZ-ALÁEZ. 1995. Aquatic Coleoptera (Hydraenidae and Elmidae) as indicators of the chemical characteristics of water in the Órbigo River basin (N-W Spain). Annals of Limnology, 31: 185-199.

GARCÍA-CRIADO,F. \& M. FERNÁNDEZ-ALÁEZ. 2001. Hydraenidae and Elmidae assemblages (Coleoptera) from a Spanish river basin: good indicators of coal mining pollution? Arch. Hydrobiol., 150: 641-660.

GARCÍA-CRIADO, F., C. FERNÁNDEZ-ALÁEZ \& M. FERNÁNDEZ-ALÁEZ. 1999.Enviromental variables influencing the distribution of Hydraenidae and Elmidae assemblages (Coleoptera) in a moderatly-polluted river basin in north-western Spain. European Journal of Entomology, 96: 37-44.

GARCÍA-CRIADO, F. \& C. TRIGAL. 2005. Comparison of several techniques for sampling macroinvertebrates in different habitats of a North Iberian pond. Hydrobiologia, 545: 103-115.

GARCÍA DE JALÓN, D. \& M. GONZÁLEZ DEL TÁNAGO. 1982. Introducción a una zoología del macrobentos en los ríos de la sierra de Guadarrama. Boletín de la Estación Central de Ecología, 11: 63-71.

GARCÍA DE JALÓN, D. \& M. GONZÁLEZ DEL TÁNAGO. 1986. Métodos biológicos para el estudio de la calidad de las aguas. Aplicación a la cuenca del Duero. ICONA- Monografías, 45. Madrid. 244 pp.

GARRIDO, J., J. A. DÍAZ \& J. A. RÉGIL. 1994. Coleópteros acuáticos de Extremadura II. (Hydraenidae, Hydrochidae, Helophoridae, Hydrophilidae, Dryopidae y Elmidae). Boletín de la Asociación Española de Entomología, 18: 113-133.

GARRIDO, J., M. FERNÁNDEZ-ALÁEZ \& J. A. RÉGIL. 1994. Geographical distribution of Adephaga and Polyphaga (Coleoptera) in the Cantabrian Mountains (Spain): Specific richness and analysis of the altitude factor. Arch. Hydrobiol., 131: 353-380.

GIL, E., C. MONTES., A. MILLÁN \& A. G. SOLER. 1990. Los coleópteros acuáticos (Hydraenidae \& Elmidae) de la cuenca del río Segura (S.E. España). Anales de Biología, 16: 23-31.

GODRON, M. 1968. Quelques applications de la notion de fréquence en écologie végétale (recouvrement, information mutuelle entre espèces et facteurs écologiques, échantillonnage). Oecologia Plantarum, 3: 185-212.

GONZÁLEZ, F., A. MIRANDA., J. R. ALONSO \& M. ABELLA. 1986a. Estudio comparativo de la calidad del agua de dos ríos Asturianos. Limnetica, 2: 217-223.

GONZÁLEZ, F., A. MIRANDA., J. R. ALONSO \& M. ABELLA. 1986b. La calidad del agua en la cuenca del río Piloña (Asturias). Limnetica, 2: 225-234.

HEUSS, K. 1989. Water beetles as indicators of water quality. The Balfour-Browne Club Newsletter, 44: 7-12.

JEFFRIES, M. 1988. Do water beetles communities reflect the wider freshwater community? The Balfour-Browne Club Newsletter, 42: 14-17.

LORENZ, A. 2004. Mid-sized Mountain Streams. Typology, Assessment and Reliability of Sampling and Assessment Methods. Ph.D. Thesis. Universität Duisburg-Essen, Germany. 146 pp.

MITOV, P. G. \& I. L. STOYANOV. 2005. Ecological profiles or harvestmen (Arachnida, Opiliones) from Vitosha Mountain (Bulgaria): a mixed modelling approach using GAMs. (generalized additive models). The Journal of Arachnology, 33: 256-268.

MORENO, J. L., A. MILLÁN., M. L. SUÁREZ., M. R. VIDAL-ABARCA \& J. VELASCO. 1997. Aquatic Coleoptera and Heteroptera assemblages in waterbodies from ephemeral coastal streams ("ramblas") of south-eastern Spain. Arch. Hydrobiol., 141: 93-107.

NUMMELIN, M., M. LODENIUS, E. TULISALO, H. HIRVONEN, \& T. ALANKO. 2007. Predatory 
insects as bioindicators of heavy metal pollution. Environmental Pollution, 145: 339-347.

OLIVEIRA, S. V. \& R. M. V. CORTES. 2005. A biologically relevant habitat condition index for streams in northern Portugal. Aquatic Conservation: Marine and Freshwater Ecosystems, 15: 189-210.

OLLER, C. \& E. GOITIA. 2005. Benthic macroinvertebrate and heavy metals in the Pilcomayo River (Tarija, Bolivia). Revista Boliviana de Ecología, 18: 17-32.

ORTIZ, J. D., E. MARTÍ, \& M. A. PUIG. 2005. Recovery of the macroinvertebrate community below a wastewater treatment plant input in a Mediterranean stream. Hydrobiologia, 545: 289-302.

PALAU, A. \& A. PALOMES. 1986. Los macroinvertebrados bentónicos como elementos de juicio para la evaluación de la calidad biológica del río Segre (Lérida, N.E. España). Limnetica, 2: 205-215.

PAZ, C. de, 1993. Hydradephaga (Coleoptera) de la cuenca del río Landro (NW Península Ibérica). Estudio faunístico y ecológico. Ph.D. Thesis. Universidad de Santiago de Compostela. $381 \mathrm{pp}$.

PETRAGLIA, A. \& M. TOMASELLI. 2003. Ecological profiles of wetland plant species in the northern Apennines (N. Italy). Journal of Limnology, 62(1): 71-78.

PRAT, N. F., G. GONZÁLEZ, X. MILLET \& M.A. PUIG. 1983. Predicció i control de la qualitat de les aigües dels rius Besós i Llobregat. II. El poblament faunistic i la seva relació amb la qualitat de les aigües. Monografies, Diputació de Barcelona, 9: 164.

PRAT, N. F., M. A. PUIG, G. GONZÁLEZ, M. F. TORT \& M. ESTRADA. 1984. Llobregat. In: Ecology of European Rivers. B.A. Whitton, (ed.): $527-$ 552. Blackwell Scientific Publications. Oxford.

PUIG, M. A. 1983. Distribución y ecología de las especies de Elmidae (Coleoptera: Dryopiodea) de la cuenca del río Llobregat. Boletin de la Asociación Española de Entomología, 7: 211-219.

RIBERA, I. 2000. Biogeography and conservation of Iberian water beettles. Biological Conservation, 92: 131-150.
RIBERA, I. \& G. N. FOSTER. 1992. Uso de los coleópteros acuáticos como indicadores biológicos (Coleoptera). Elytron, 6: 61-75.

RIBERA, I., J. ISART \& J. A. RÉGIL. 1995a. Autoecología de algunas espécies de Hydradephaga (Coleoptera) de los Pirineos. I. Gyrinidae, Haliplidae, Noteridae e Hygrobiidae. Zoologica baetica, 6: 33-58

RIBERA, I., J. ISART \& J. A. RÉGIL. 1995b. Autoecología de algunas espécies de Hydradephaga (Coleoptera) de los Pirineos. II. Dytiscidae. Zoologica baetica, 6: 59-104.

SÁINZ-CANTERO, C. E., A. SÁNCHEZ-ORTEGA \& J. ALBA-TERCEDOR. 1987. Distribución y autoecología de Hydraenidae (Col.) en Sierra Nevada (España). Boln. Asoc. Esp. Ent., 11: 355-365.

SÁINZ-CANTERO, C. E., C. ZAMORA-MUÑOZ \& J. ALBA-TERCEDOR. 1988. Coleópteros acuáticos del río Monachil (Sierra Nevada, España). Elytron, 2: 97-106.

SMOLDERS, A. J. P., G. VAN HENGSTUM, J. LOERMANS, A. MONTES, H. RIZO e I. CASTILLO. 1999. Efectos de la Contaminación Minera sobre la Composición de la Macrofauna Bentónica en el Río Pilcomayo. Revista Boliviana de Ecología, 6: 229-237.

SMOLDERS, A. J. P., A. A. C. LOCK, G. VAN DER VELDE, R. I. MEDINA HOYOS \& J. G. M. ROELOFS. 2003. Effects of Mining Activities on Heavy Metal Concentrations in Water, Sediment and Macroinvertebrates in Different Reaches of the Pilcomayo River, South America. Archiv. of Environmental Contamination and Toxicology, 44: 314-323.

TER BRAAK, C. J. F. \& O. F. R. VAN TONGEREN. 1995. Data Analysis in Community and Landscape Ecology. Cambridge University Press: Cambridge. 299 pp.

VALLADARES, L. F., C. FERNÁNDEZ-ALÁEZ \& M. FERNÁNDEZ-ALÁEZ. 1990. Influence of altitude in the distribution of the aquatic Hydrophiloidea (Coleoptera) in the province of León (NW Spain). Limnetica, 6: 79-86. 